\title{
Revision of the Afrotropical planthopper genus Centromeriana Melichar, 1912 (Hemiptera, Dictyopharidae)
}

\author{
Zhi-Shun SONG ${ }^{1}$, Igor MALENOVSKÝ ${ }^{2}$ \& Ai-Ping LIANG ${ }^{3, *}$ \\ ${ }^{1,3}$ Key Laboratory of Zoological Systematics and Evolution, Institute of Zoology, \\ Chinese Academy of Sciences, Beijing 100101, China. \\ ${ }^{2}$ Department of Botany and Zoology, Faculty of Science, \\ Masaryk University, Kotlářská 2, 61137 Brno, Czech Republic. \\ ${ }^{*}$ Corresponding author: liangap@ioz.ac.cn \\ 1Email: songzs@ioz.ac.cn \\ 2Email: malenovsky@sci.muni.cz \\ ${ }^{1} \underline{\text { urn:1sid:zoobank.org:author:B566EA8A-3A99-4DA8-830D-3DBF07E211D9 }}$
${ }^{2}$ urn:1sid:zoobank.org:author:8AF430DB-BBBD-4F48-92CA-259290924F71
${ }^{3}$ urn:1sid:zoobank.org:author:862BAA85-A5A9-44DE-A6E4-99D30C39B2C9
}

\begin{abstract}
The Afrotropical planthopper genus Centromeriana Melichar, 1912 (Hemiptera, Fulgoromorpha, Dictyopharidae, Dictyopharinae, Orthopagini) is revised. Four species are included: C. jocosa (Gerstaecker, 1895) (the type species, with confirmed records from Cameroon, Equatorial Guinea and Gabon), C. lindbergae sp. nov. (described from Sierra Leone), C. rhinoceros sp. nov. (described from Togo) and C. simplex Melichar, 1912 (so far only known from Equatorial Guinea, Bioko island). Lectotypes are designated for C. jocosa and C. simplex and both species are redescribed including habitus photographs and detailed illustrations of the male and female genitalia which are published for the first time. A key for identification of the species of Centromeriana is provided. As far as known, the genus is endemic to the (Guineo-)Congolian region of western Africa.
\end{abstract}

Keywords. Afrotropic, Auchenorrhyncha, morphology, new species, planthopper.

Song Z.-S., Malenovský I. \& Liang A.-P. 2017. Revision of the Afrotropical planthopper genus Centromeriana Melichar, 1912 (Hemiptera, Dictyopharidae). European Journal of Taxonomy 278: 1-21. http://dx.doi. org/10.58552/ejt.2017.278

\section{Introduction}

The family Dictyopharidae is one of twenty currently recognized extant families of planthoppers (Hemiptera, Fulgoromorpha) (Bourgoin 2016). It is closely related to lanternflies (Fulgoridae) and many members of both taxa are conspicuous for their elongated head (Urban \& Cryan 2009). The biology of most Dictyopharidae is poorly known, but both adults and nymphs are phytophagous and suck phloem sap from above-ground portions of plants. Most species are known to be associated with dicotyledonous herbs, dwarf shrubs or trees but there are also some dictyopharids feeding on grasses (Wilson et al. 
1994; Bartlett et al. 2014). Dictyopharidae currently includes approximately 740 described species in 169 genera, most of which are distributed in tropical and subtropical regions (Song et al. 2014, 2016b; Bourgoin 2016). In the Afrotropical region, 104 species are known from sub-Saharan continental Africa (Stroiński \& Szwedo 2015).

Dictyopharidae is currently divided into two subfamilies. The larger nominotypic Dictyopharinae is further split in 13 extant tribes (Emeljanov 2011; Song et al. 2016b). One of them is Orthopagini erected by Emeljanov (1983) for Orthopagus Uhler, 1896, and six other genera and later extended to include a total of 23 extant and one fossil genera (Emeljanov 2011; Emeljanov \& Shcherbakov 2011; Song et al. 2016c). The Orthopagini taxa are mainly distributed in the Old World tropics and subtropics including sub-Saharan Africa, India, Sri Lanka, southern China, Indochina, Malaya, the Greater Sunda Islands, the Philippines, the Moluccas, and northern Australia; a few species of Orthopagus and Saigona Matsumura, 1910, extend into the eastern Palaearctic region (Song et al. 2016c). While the Oriental and eastern Palaearctic Orthopagini were mostly revised by the first author and his collaborators (Liang \& Song 2006; Song \& Liang 2006a, 2006b, 2007, 2011, 2012a, 2012b; Song et al. 2012, 2014, 2016c), the taxonomy and morphology of the Afrotropical genera and species are still only poorly known with the exception of Fernandea Melichar, 1912, recently redescribed by Song et al. (2016a).

Here we review the genus Centromeriana, originally established for Centromeriana jocosa (Gerstaecker, 1895) and C. simplex Melichar, 1912, from westernAfrica (Melichar 1912). We redescribe the morphology of these two species in detail based on the type material and add two new species, C. lindbergae sp. nov. from Sierra Leone and C. rhinoceros sp. nov. from Togo. We provide an identification key and photographic illustrations for each species showing also the structures of the male and female genitalia which have never been described and illustrated in literature for Centromeriana. Besides an easier identification of these species, this information should also help to analyze phylogenetic relationships of Centromeriana within Dictyopharidae in future.

\section{Material and methods}

The specimens studied in the course of this work are deposited in the following institutions, which are subsequently referred to by their acronyms:

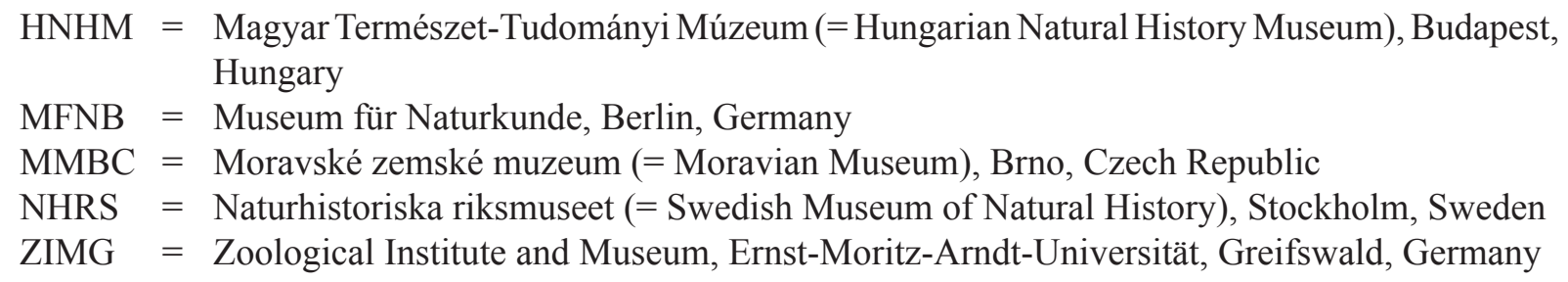

The post-abdomina of the specimens used for dissections were cleared in $10 \% \mathrm{KOH}$ at room temperature for ca 6-12 hours, rinsed and examined in distilled water and then transferred to $10 \%$ glycerol and enclosed in microvials to be preserved with the specimens. Observations were conducted under a stereo microscope, measurements and photography under a Leica Z16 APO A macroscope equipped with a Leica DFC495 microscope camera and Leica Application Suite software (version 3.7.0). Some final images were compiled from multiple photographs using CombineZM image stacking software and improved with the Adobe Photoshop CS5 software.

The morphological terminology and measurements used in this study follow Song et al. (2016b, 2016c) for most characters, Bourgoin (1993) for the female genitalia, and Bourgoin et al. (2015) for the forewing. The genus-level features are not repeated in species-level descriptions. 


\section{Results}

Class Hexapoda Blainville, 1816

Order Hemiptera Linnaeus, 1758

Infraorder Fulgoromorpha Evans, 1946

Family Dictyopharidae Spinola, 1839

Tribe Orthopagini Emeljanov, 1983

Genus Centromeriana Melichar, 1912

Figs 1-8

Centromeriana Melichar, 1912: 45.

Centromeriana - Schmidt 1915: 349 (in list of material). — Metcalf 1946: 39 (in catalogue). — Fennah 1958a: 52 (in key).

\section{Type species}

Dictyophara jocosa Gerstaecker, 1895 (original designation).

\section{Emended diagnosis}

The genus can be distinguished by the following combination of characters: cephalic process moderately long and slender, conical and strongly curved upward; vertex with lateral carinae abruptly constricted and strongly upturned in front of eyes, then gradually convergent anteriad and acuminate at apex; frons with median carina robust and strongly convex, intermediate carinae distinctly expanded outward in apical third, their apical portion being distinctly visible in posterodorsal view; genae with a longitudinal carina above eyes; pronotum with median carina sharp and high, intermediate carinae absent; forewings with sparse transverse veins, stigmal area small and quadrangular, with two or three cells; legs elongate and slender, fore femur not flattened and dilated, without spine; hind tibia with eight apical teeth; apical spines of tarsomeres with long setae; female abdominal sternite VII with a pair of large horn-shaped spines strongly produced ventrad near anterior margin and a pair of blunt triangular lobes on posterior margin; gonocoxae VIII with a pair of small triangular sclerotized plates on posterolateral margin of endogonocoxal lobes.

\section{Redescription}

HeAD (Figs 4A-C, 6A-C, 7A-C, 8A-C). Produced into a moderately long and slender cephalic process. Cephalic process (Figs 4B, 6B, 7B, 8B) conical, strongly curved upward, and gradually narrowed toward apex. Vertex (Figs 4A, 6A, 7A, 8A) broadest at base, basal width narrower than transverse diameter of eyes, posterior plane elevated above pronotum; lateral carinae strongly ridged, foliaceous, and sub-parallel in basal third, abruptly constricted and strongly upturned in front of eyes, then gradually convergent anteriad, and acuminate at apex; posterior margin of vertex ridged and angularly concave at about $90-100^{\circ}$; median carina distinct on a bulge between eyes. Frons (Figs 4C, 6C, 7C, 8C) with lateral carinae ridged, nearly parallel, slightly expanded outward below antennae; intermediate carinae slightly converging posteriorly and nearly approaching to frontoclypeal suture, but only sharp and distinct in apical third where they are distinctly expanded outward in ventral view and curved anterodorsad in lateral view, so their apical portion is distinctly visible in posterodorsal view; median carina robust and strongly convex in lateral view. Postclypeus and anteclypeus (Figs 4C, 6C, 7C, 8C) convex medially, with distinct median carina. Rostrum very long, surpassing middle of hind femora; basal segment distinctly longer than distal one. Genae (Figs 4B, 6B, 7B, 8B) with a longitudinal carina above eyes, appearing as bifurcated from lateral carinae of vertex in dorsal view (Figs 4A, 6A, 7A, 8A). Compound eyes (Figs 4A-C, 6A-C, 7A-C, 8A-C) large and globose. Ocelli (Figs 4B, 6B, 7B, 8B) relatively large, 
reddish. Antenna (Figs 4B, 6B, 7B, 8B) with very small scape; pedicel large and subglobose, with more than 50 distinct sensory plaque organs distributed over entire surface; flagellum long, setuliform.

Thoarax. Pronotum (Figs 4A, 6A, 7A, 8A) distinctly shorter than mesonotum medially, narrow anteriorly, broad posteriorly; anterior margin pointed medially, forming a sharp angle, lateral marginal

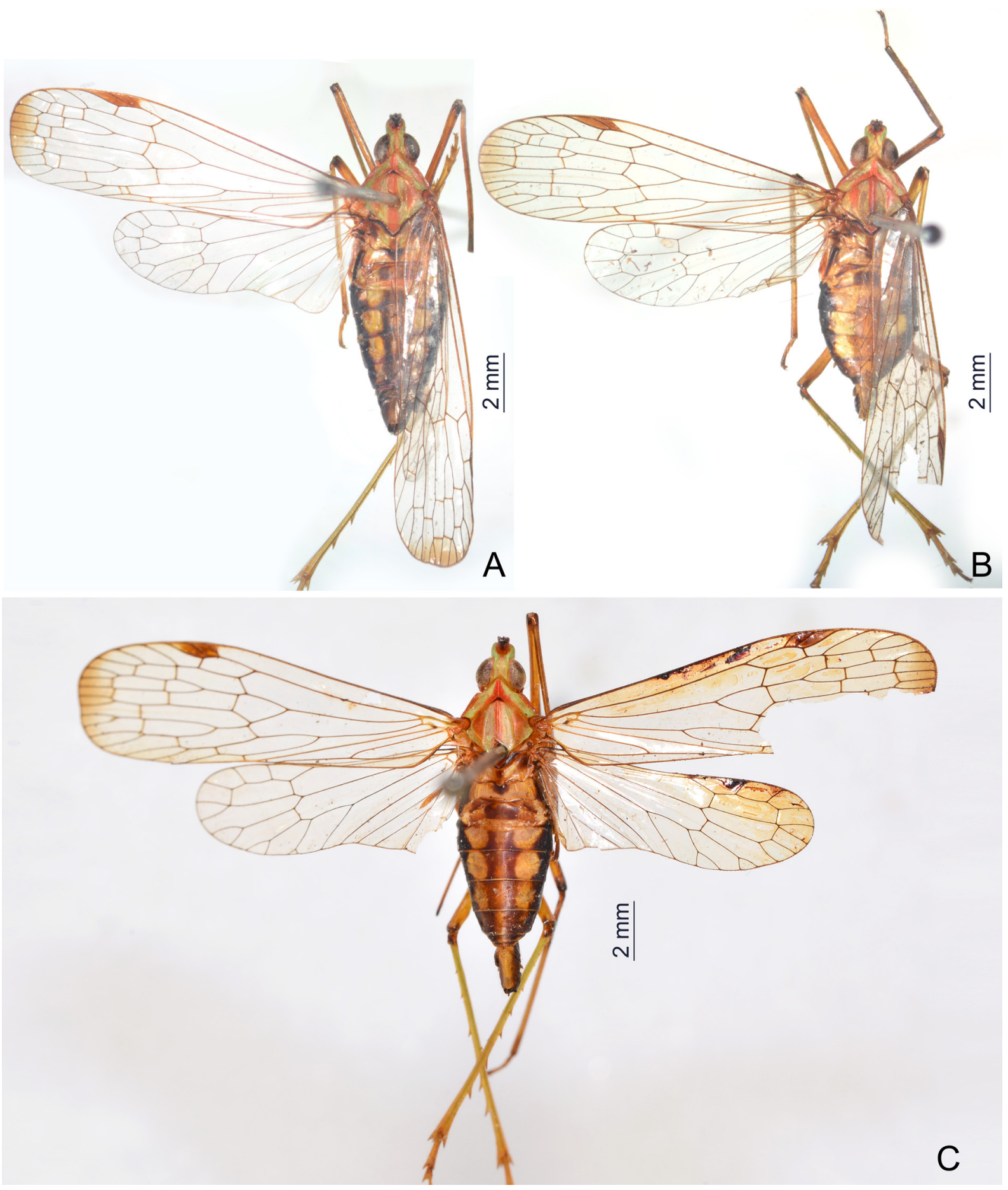

Fig. 1. Habitus of Centromeriana species. A. C. jocosa (Gerstaecker, 1895), †, dorsal view. B. C. lindbergae sp. nov., holotype, $\hat{\jmath}$, dorsal view. C. C. jocosa, $\hat{\jmath}$, dorsal view. 


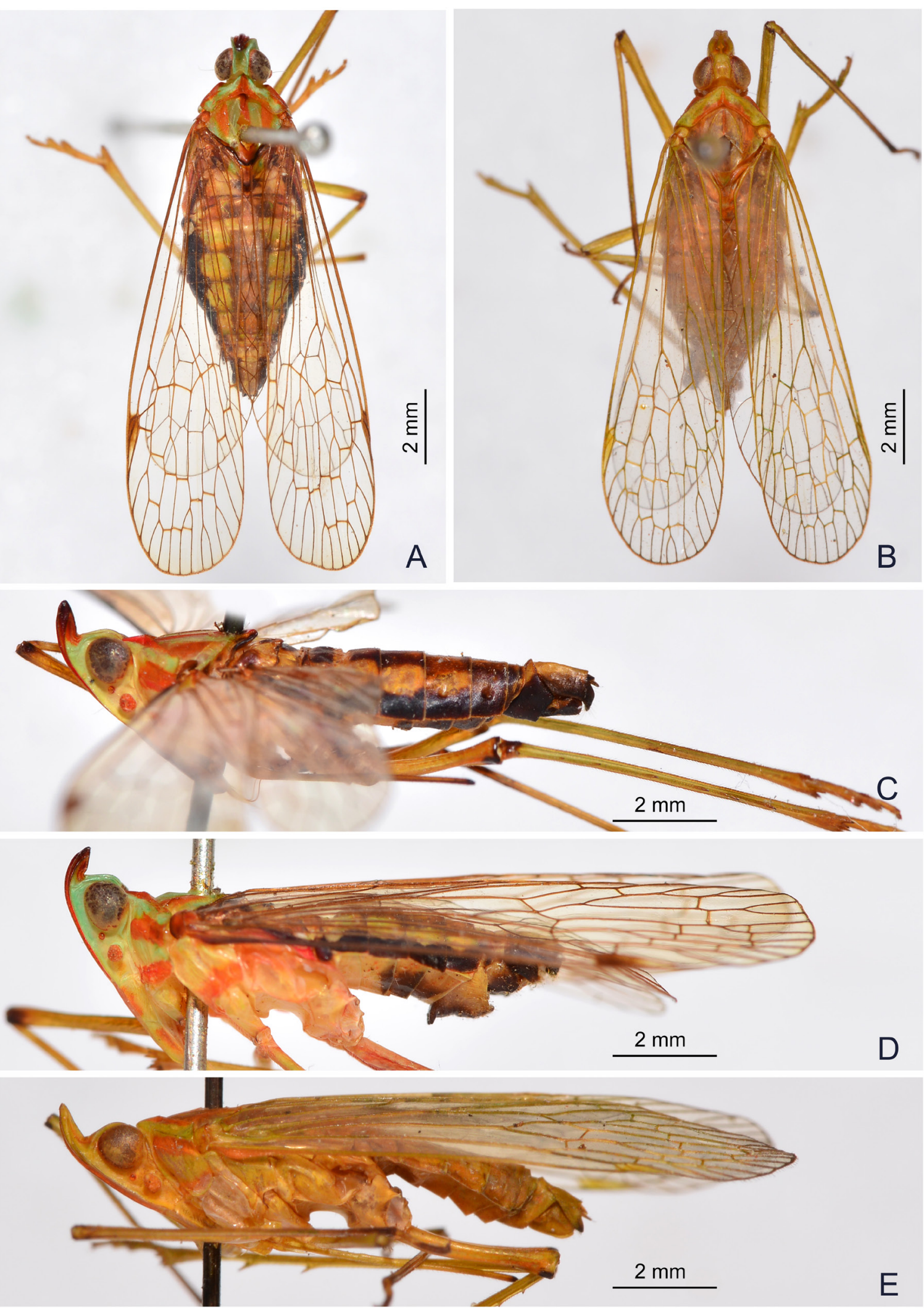

Fig. 2. Habitus of Centromeriana species. A. C. rhinoceros sp. nov., holotype, $\circ$, dorsal view. B. C. simplex Melichar, 1912, lectotype, ô, dorsal view. C. C. jocosa (Gerstaecker, 1895), ô, lateral view. D. C. rhinoceros sp. nov., holotype,, , lateral view. E. C. simplex, lectotype, ô, lateral view. 
areas straight and sloping with two long longitudinal carinae on each side between eyes and tegulae, lower lateral carinae expanded and visible in dorsal view; posterior margin angularly concave at about $100-110^{\circ}$; median carina sharp and high, with a lateral pit on each side, intermediate carinae absent. Mesonotum (Figs 4A, 6A, 7A, 8A) tricarinate, lateral carinae incurved anteriorly toward median carina. Forewings (Fig. 3A-D) hyaline, much longer than abdomen, with ratio of length to width about 3:1; veins with short setae on ventral side; venation with sparse transverse veins; MP bifurcating $\mathrm{MP}_{1+2}$ and $\mathrm{MP}_{3+4}$ near middle and beyond $\mathrm{CuA}$; number of apical cells between $\mathrm{R}$ and $\mathrm{CuA}$ equal to 14; stigmal area small and quadrangular, with two or three cells. Legs elongate and slender, fore and middle femora distinctly elongate, fore femur not flattened and dilated, without spine near apex; hind tibia with 5-7 lateral spines and eight apical teeth; hind tarsomeres I and II each with 7-8 apical spines; apical spines of tarsomeres with long setae instead of platellae.

AвDOMEN. With pregenital segments elongate and broad, without distinct median and intermediate carinae dorsally. Female abdominal sternite VII with a pair of large horn-shaped spines directed ventrad near anterior margin and a pair of blunt triangular lobes on posterior margin (Fig. 5A).

Male Genitalia. Pygofer (Figs 4D-F, 6D-F, 8D-F) in lateral view distinctly wider ventrally than dorsally, dorsal margin slightly excavated to accommodate segment $\mathrm{X}$, dorsoposterior margins angular. Gonostyles (Figs 4E, 6G, 8G) symmetrical, base narrow, expanded toward apex, broadest subapically; dorsal margin with a claw-like, sclerotised process at apex directed dorsad, outer dorsal edge with a hook-like sclerotised process near middle directed ventrad. Aedeagus (Figs 4G-I, 6H-J, 8H-J) with one pair of long endosomal processes extended from phallotheca or lacking such processes; phallobase sclerotised basally and membranous and inflated apically, with paired lobes covered with numerous minute superficial spines (Figs 4G-I, 6H-J) or without spines (Fig. 8H-J). Segment X (Figs 4D, 6D, 8D) large, in dorsal view with apex deeply excavated to accommodate anal style; anal style elongate and large.

Female Genitalia (Fig. 5A-G). Gonocoxae VIII (Fig. 5E) with two membranous and flattened endogonocoxal processes (Gxp) on endogonocoxal lobe: Gxp1 large and elongate, with a long sclerotized plate in it; Gxp2 smaller and shorter. A pair of small triangular sclerotized plates on posterolateral margin of endogonocoxal lobes (Fig. 5A). Gonapophyses VIII (Fig. 5E) with anterior connective lamina large and sclerotized, with seven teeth of varying sizes and shapes. Gonapophyses IX (Fig. 5F) with posterior connective lamina triangular, symmetrical, fused with the intergonocoxal plate at base; intergonocoxal

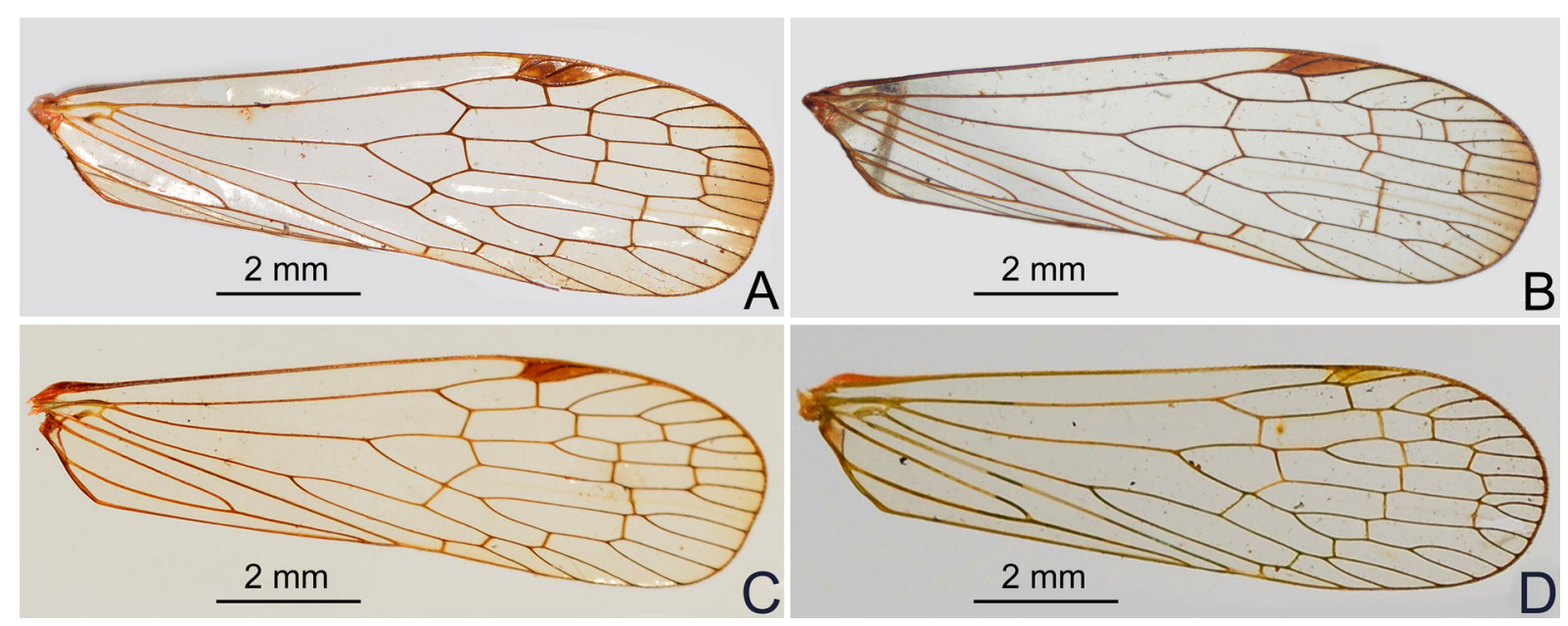

Fig. 3. Forewing of Centromeriana species. A. C. jocosa (Gerstaecker, 1895). B. C. lindbergae sp. nov. C. C. rhinoceros sp. nov. D. C. simplex Melichar, 1912. 
plate extended cephalad into genital cavity, forming wall of gonospiculum. Gonoplacs (Fig. 5G) with two lobes homologous; lateral lobe large and moderately sclerotized, with long setae at apex; the posterior lobe membranous, containing long sclerotized plate. Segment X (Fig. 5D) large and broad in dorsal view, apex deeply excavated to accommodate anal style; anal style large and elongate. Female ectodermal genital ducts ditrysian. Bursa copulatrix (Fig. 5B) superficially membranous, regularly gridded, without sclerotized ornamentations. A pair of large digitiform glands (Fig. 5B) branched at anterior extremity of the anterior vagina on each side of the spermatheca. Spermatheca (Fig. 5B) divided clearly into five parts: orificium receptaculi, ductus receptaculi, diverticulum ductus, pars intermedialis, and glandula apicalis.

\section{Diversity and distribution}

Centromeriana is comprised of four species being endemic to the Congolian region of the western tropical Africa as defined by Linder et al. (2012) and closely matching to the Guineo-Congolian region of White $(1979,1983)$ including the 'Dahomey gap'.

\section{Ecology and economic importance}

Unknown. Heinrichs \& Barrion (2004) listed Centromeriana sp. among insects occurring on rice in Gambia. However, based on morphological characters they specify in their identification key (p. 155) and a schematical drawing of the head and thorax (fig. 355: 157), this is a misidentification; the record probably refers to some other dictyopharid genus. Oke et al. (2015) reported adult Centromeriana spp. as minor pests of leaves of Amaranthus spp. in Nigeria but the identification is uncertain.

\section{Key to species of Centromeriana}

1. Forewing membrane with a fuscous macula apically (Fig. 3A-B) ................................................. 2

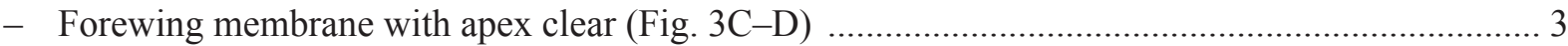

2. Phallobase with ventral lobes robust and thumb-like, broad apically, confluent medially (Fig. 4H-I). Male segment $X$, in dorsal view, narrow, ratio of length to width near middle about 2.2:1 (Fig. 4D); in lateral view, with narrow and sharp, hook-like apical lobes, strongly projecting ventrad (Fig. 4E) C. jocosa (Gerstaecker, 1895)

- Phallobase with ventral lobes more slender, convergent and tapering apically, but divergent medially (Fig. 6I, J). Male segment X, in dorsal view, broad, ratio of length to width near middle about 1.3:1 (Fig. 6D); in lateral view, with broad and blunt apical lobes, weakly projecting ventrad (Fig. 6E) C. lindbergae sp. nov.

3. Abdomen dorsally and ventrally dark brown and black, with a longitudinal row of yellowishochraceous spots on each side (Fig. 2A). Cephalic process relatively short, curved upward and slightly backward in more than $90^{\circ}$ (Fig. 7B) C. rhinoceros sp. nov.

- Abdomen dorsally and ventrally greenish-ochraceous (Fig. 2B). Cephalic process relatively long, curved upward in nearly $90^{\circ}$ (Fig. 8B). Male genitalia as in Fig. 8D-J ...C. simplex Melichar, 1912

Centromeriana jocosa (Gerstaecker, 1895)

Figs $1 \mathrm{~A}, \mathrm{C}, 2 \mathrm{C}, 3 \mathrm{~A}, 4 \mathrm{~A}-\mathrm{I}, 5 \mathrm{~A}-\mathrm{G}$

Dictyophara jocosa Gerstaecker, 1895: 13.

Centromeriana jocosa - Melichar 1912: 45 (redescription, key, records from Cameroon and Equatorial Guinea). - Schmidt 1915: 349 (record from the Democratic Republic of Congo). - Metcalf 1946: 40 (catalogue). - Fennah 1958a: 56 (record from the Democratic Republic of Congo). — Lallemand 1958: 225 (record from Guinea). 

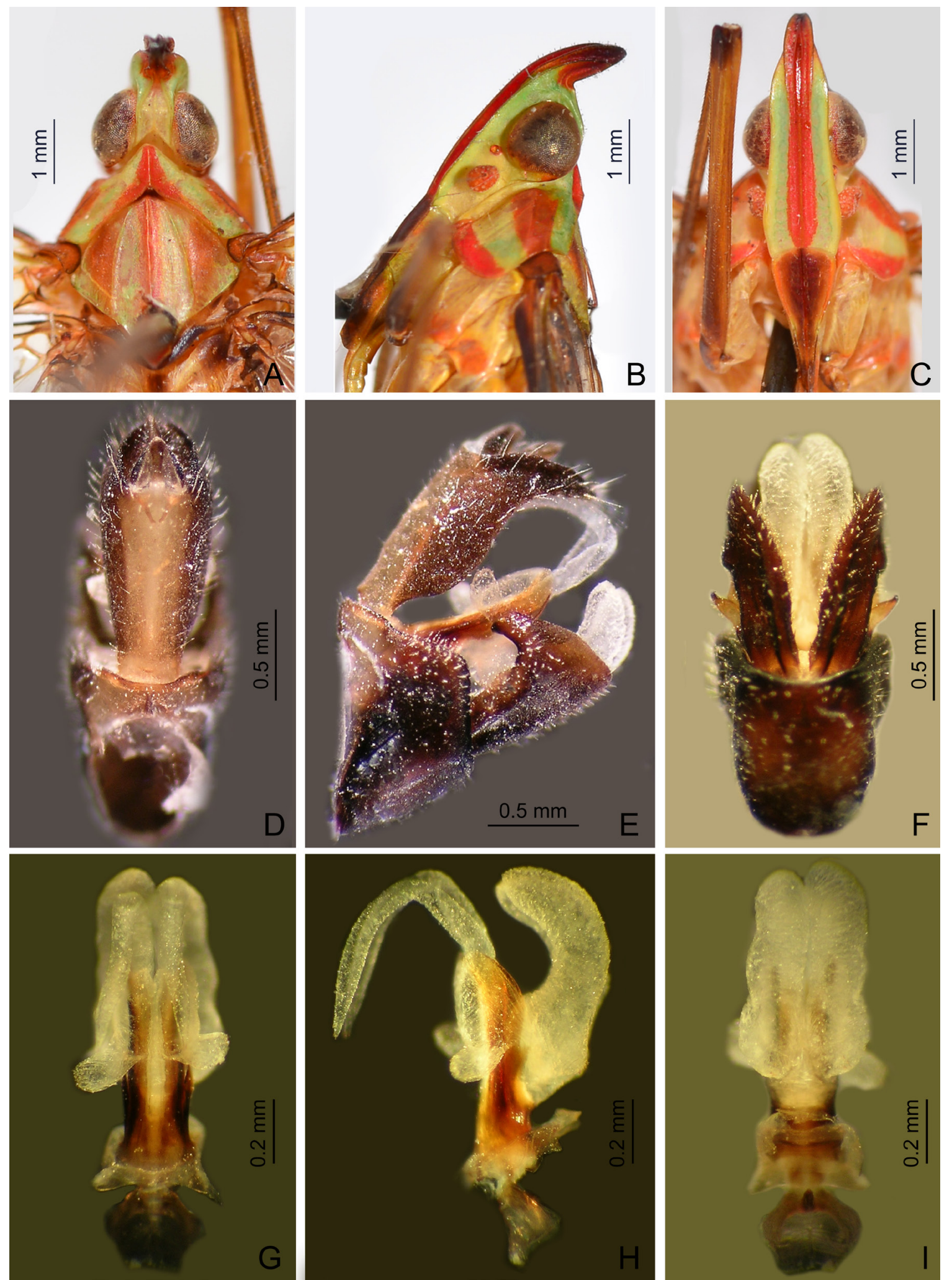

Fig. 4. Centromeriana jocosa (Gerstaecker, 1895). A. Head, pronotum and mesonotum, dorsal view. B. Head and pronotum, lateral view. C. Head and pronotum, ventral view. D. Male segment X and pygofer, dorsal view. E. Male pygofer, gonostyles, and segment X, lateral view. F. Male pygofer and gonostyles, ventral view. G. Aedeagus, dorsal view. H. Aedeagus, lateral view. I. Aedeagus, ventral view. 


\section{Type material examined}

Lectotype (here designated)

CAMEROON: ${ }^{\Uparrow}$, "jocosa Gerst.*, Centromeria, Victoria. Buchh. [handwritten dark blue label pinned in the collection next to the specimen]; Zool. Mus. Greifswald, II 27382; Victoria (Camerun), Buchholz leg. (labelled by I. Malenovský, 2016) [newly added white printed label pinned to the specimen]; LECTOTYPUS ${ }^{\wedge}$, Dictyophara jocosa Gerstaecker, 1895, desig. Z.S. Song, I. Malenovský \& A.P. Liang, 2016 [newly added red label pinned to the specimen]" (ZIMG; dry-mounted: pinned through mesonotum, left foreleg and apical half of left forewing missing).

\section{Other material examined}

CAMEROON: 1 o, "Kamerun, Conradt; Centromeriana jocosa Gerst. [Melichar's handwriting], det. Melichar." (MMBC); 1 ㅇ "N. Kamerun, Joh. Albrechtshöhe, 14.VII-17.VIII.[18]96, L. Conradt; 14/717/8.[18]96; jocosa [Melichar's handwriting], det. Melichar." (MMBC); 1 ㅇ, "N. Kamerun, Johann Albrechtshöhe, L. Conradt; 21/10.[18]95; Centromeriana jocosa Gerst. [Melichar's handwriting]"

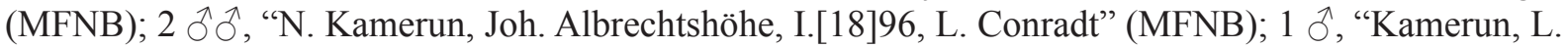
Conradt" (MFNB).

EQUATORIAL GUINEA: 1 o, "Fernando Póo [= Bioko island], Isab. [= Santa Isabel = the city of Malabo]; Centromeriana jocosa Ger. [Melichar's handwriting], det. Melichar" (MMBC); 2 § $\widehat{\partial}, 2$ 우, "Span. Guinea, Nkolentangan [near Alén in mainland Equatorial Guinea], 7.XI-8.V [1907-1909], G. Teßmann; Centromeriana jocosa Gers. [Synave's handwriting], H. Synave det., 1969” (MFNB).

GABON: 1 q “NHRS-GULI 000009123; Gabun.; Staudgr. [= O. Staudinger]” (NHRS).

\section{Redescription}

LENGTH. Body length (from apex of head to tip of forewings): o $14.1-16.9 \mathrm{~mm}$, $+16.5-17.7 \mathrm{~mm}$; head length (including two portions: the former is from apex of cephalic process to constricted and curved part, and the latter is from curved part to base of eyes): $\sigma^{\lambda}(0.8-1.0)+(1.0-1.2) \mathrm{mm}$, o $(0.8-1.1)+(1.1-1.2) \mathrm{mm}$;

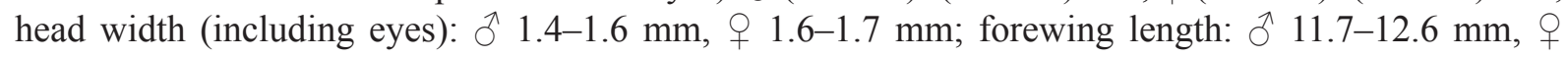
$12.3-13.0 \mathrm{~mm}$.

Coloration. General color (Figs 1A, C, 2C) brownish ochraceous marked with pale green and purplish-red on head and thorax, and dark brown and black on abdomen in dorsal view. Head pale green or yellow, head apex (cephalic process) purplish-red to dark brown, frons between intermediate carinae including median carina purplish-red. Clypeus dark purplish red to dark brown. Pronotum and mesonotum greenish or yellowish ochraceous, median carina along with posterior margin, areas behind eyes including lateral carinae and apical margins of paranotal lobes on pronotum, and three broad stripes on mesonotum medially and laterally all purplish-red. Tegulae purplish red. Forewing and hindwing membrane hyaline, except an unsharply delimited brownish macula at apex of forewings; venation brown, stigmal area brown. Thorax greenish or yellowish ochraceous ventrolaterally with an orange or purplish red band adjacent to base of hind coxae. Legs yellowish green, basal sections of femora, apices of fore and middle tibiae and lateral and apical spines all fuscous, apices of all femora dark brown to black. Abdomen dorsally dark brown and black with a paler brownish midline and a longitudinal row of large round yellowish ochraceous spots on each side or abdomen dorsally more or less uniformly yellowish ochraceous and dark brown to black only laterally; ventrally mostly blackish brown, posterior margins of sternites yellowish ochraceous; male and female terminalia dark brown, segment X dorsally yellowish ochraceous.

Male Genitalia. Pygofer in lateral view (Fig. 4E) large and broad, dorso-posterior margin obtusely angular; in ventral view (Fig. 4F) much longer than in dorsal view (Fig. 4D) with ratio of ventral to 
dorsal length about 4.0:1. Gonostyles (Fig. 4E-F) symmetrical, sicle-shaped, relatively narrow basally, slightly expanding towards apex, broadest subapically, apex straight; dorsal claw-like process large, elongate, and acute apically. Aedeagus (Fig. 4G-I) with endosomal processes (Fig. 4G-H) elongate, membranous and acute apically, extended posteriad and strongly curved dorso-anteriad, apex with some minute spines; phallobase sclerotized and pigmented at base, membranous and inflated apically, with one pair of short and thumb-like dorsolateral lobes directed laterad, their apex bearing minute spines (Fig. 4G), and one pair of robust, elongate, thumb-like (apically broad) ventral lobes, confluent, curved and directed dorso-posteriad, base with some minute spines (Fig. 4I). Segment X, in lateral view, with apical lobes hook-shaped: narrow, sharp and strongly projecting ventrad (Fig. 4E); in dorsal view, relatively narrow and elongate, ratio of length to width near middle about 2.2:1 (Fig. 4D).
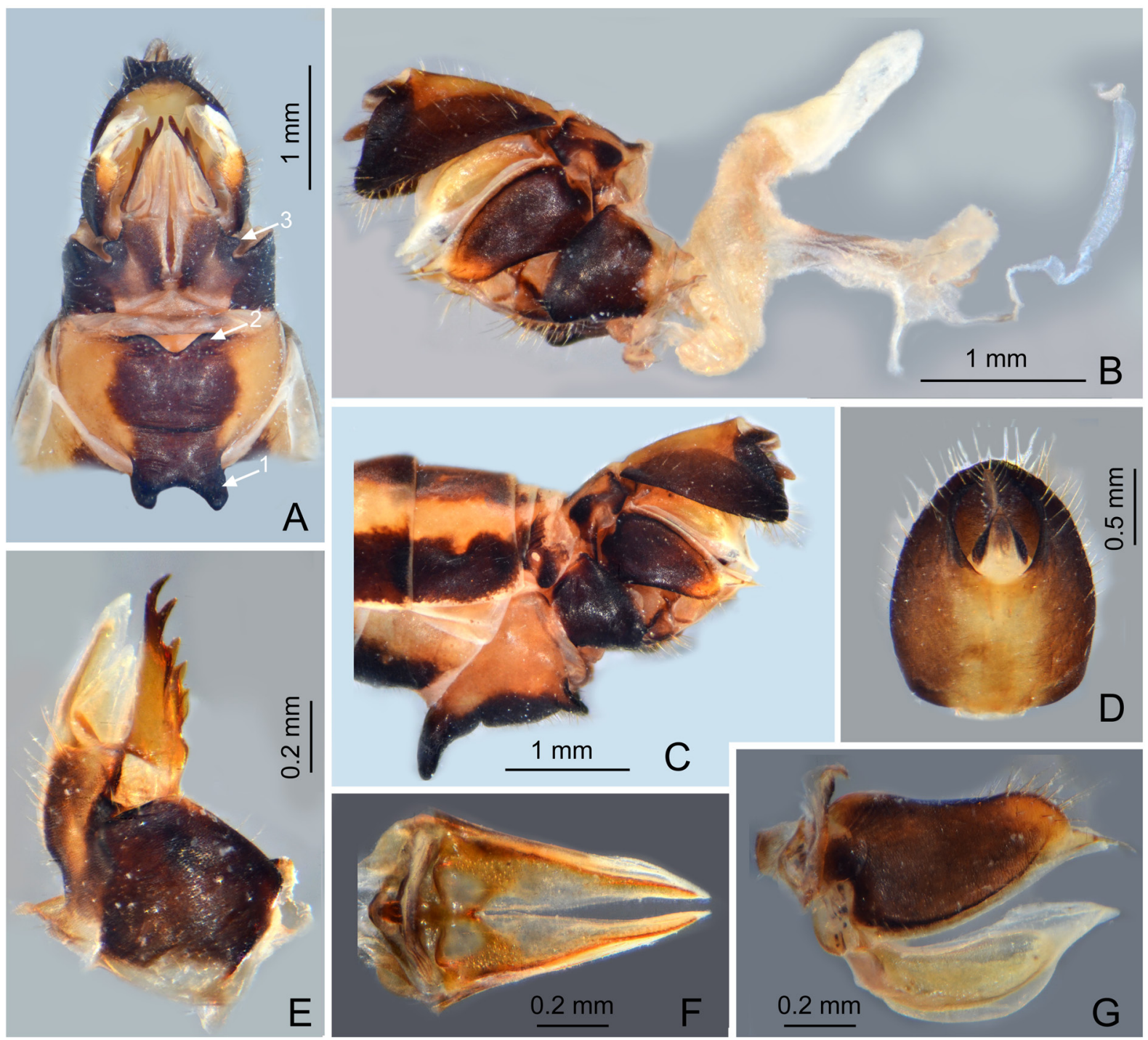

Fig. 5. Centromeriana jocosa (Gerstaecker, 1895). A. Female terminalia with sternite VII with a pair of large horn-shaped spines near anterior margin (arrow 1) and a pair of short and blunt lobes on posterior margin (arrow 2), and gonocoxae VIII with a pair of small triangular sclerotized plates on posterolateral margin of endogonocoxal lobes (arrow 3), ventral view. B. Female terminalia and ectodermal genital ducts, right lateral view. C. Female terminalia showing the horn-shaped spines on abdominal sternite VII, left lateral view. D. Female segment X, dorsal view. E. gonapophysis VIII, dorsolateral view. F. Gonapophysis IX, ventral view. G. Gonoplacs, lateral view. 
Female genitalia (Fig. 5A-G) as in generic description.

\section{Distribution}

Cameroon, Equatorial Guinea and Gabon; also reported Democratic Republic of the Congo (Schmidt 1915; Fennah 1958a) and Guinea (Lallemand 1958) but these require verification. The record from Sierra Leone (Melichar 1912) is here referred to as C. lindbergae sp. nov.

\section{Remarks}

Gerstaecker (1895) described C. jocosa based on material from "Victoria" (= Limbe, $4^{\circ} 01^{\prime} \mathrm{N}, 9^{\circ} 13^{\prime} \mathrm{E}$ ), Cameroon but did not provide any further details on the type series; he particularly did not state the number and sex of the specimens he used for the description nor did he designate a holotype. In the Gerstaecker collection in ZIMG, there is a single male of $C$. jocosa. It fully conforms the original description including the associated locality data. Following the Recommendation $73 \mathrm{~F}$ and Article 74 of ICZN (1999), we designate this specimen as the lectotype to stabilize the nomenclature in the genus.

Centromeriana lindbergae sp. nov. urn:Isid:zoobank.org:act:B6EE7817-C8D3-413F-9301-251C6389C5DB

Figs 1B, 3B, 6A-J

Centromeriana jocosa auct., nec Gerstaecker, 1895 (in part): 13.

Centromeriana jocosa-Melichar 1912: 45 (record from Sierra Leone).

\section{Diagnosis}

Centromeriana lindbergae sp. nov. is very similar to C. jocosa in size, coloration and body structure but can be differentiated from the latter by the structure of the male genitalia: the segment $\mathrm{X}$ (anal tube) which is broad in dorsal view and with broad and blunt apical lobes, weakly projecting ventrad in lateral view (in C. jocosa, the segment $\mathrm{X}$ is much narrower and elongate in dorsal view and with narrow, sharp, hook-like apical lobes strongly projecting ventrad in lateral view); and the aedeagus which has relatively short and only slightly curved endosomal processes, the apices of which are directed dorso-posteriad (in C. jocosa, the endosomal processes are longer and more strongly curved, with apices directed dorso-anteriad), and the ventral lobes of the phallobase are more slender, convergent and tapering apically, but divergent medially (in $C$. jocosa, they are robust and thumb-like, broad apically and confluent medially). Centromeriana lindbergae sp. nov. differs from C. rhinoceros sp. nov. in the presence of a brownish macula on the forewing apex and a less inclined cephalic process. Centromeriana lindbergae sp. nov. differs from C. simplex in a darker body coloration pattern, the presence of a brownish macula on the forewing apex, and the structure of the male genitalia, particularly a broader segment X (narrower in C. simplex), obtusely angled dorsoposterior margin of pygofer (right-angled in C. simplex), a more slender and sicle-shaped gonostyle (robust and triangular in C. simplex), and the aedeagus with long endosomal processes (absent in C. simplex) and differently shaped and sized lobes of the phallobase (C. simplex has large and broad triangular dorsal lobes, expanded laterally).

\section{Etymology}

The new species is named after Ms. Gunvi Lindberg, manager of the Hemiptera collection and the microscopic slide collection at the Naturhistoriska riksmuseet, Stockholm, Sweden, in recognition of her kindest help and support to the first author when he visited NHRS in 2014. 

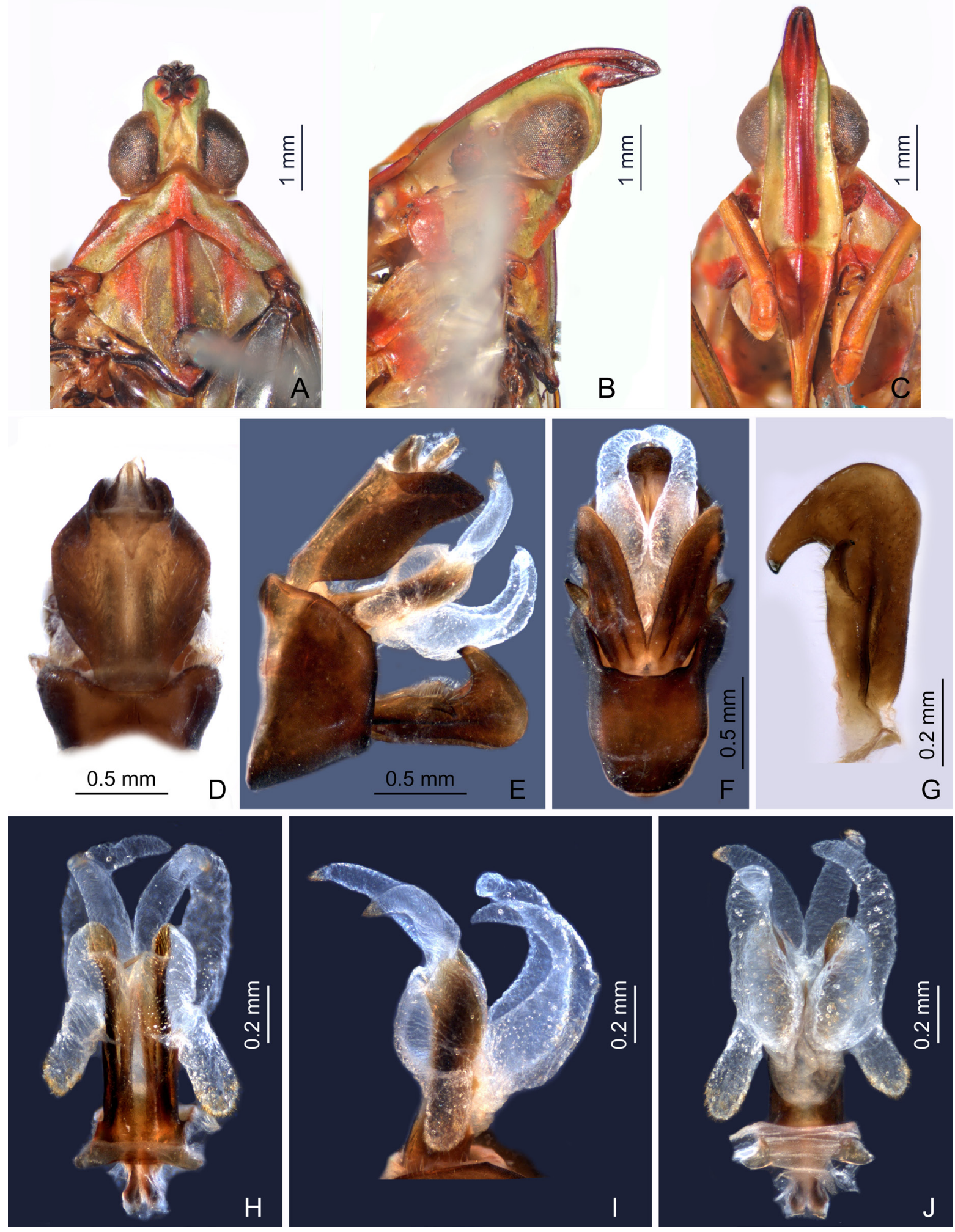

Fig. 6. Centromeriana lindbergae sp. nov., holotype, $\partial^{\widehat{\lambda}}$ (head), and paratype, $\widehat{\partial}$ (male genitalia). A. Head, pronotum and mesonotum, dorsal view. B. Head and pronotum, lateral view. C. Head and pronotum, ventral view. D. Male segment $\mathrm{X}$ and pygofer, dorsal view. E. Male pygofer, gonostyles, and segment $\mathrm{X}$, lateral view. F. Male pygofer and gonostyles, ventral view. G. Left gonostyle, outer maximum view. H. Aedeagus, dorsal view. I. Aedeagus, lateral view. J. Aedeagus, ventral view. 


\section{Type material examined}

\section{Holotype}

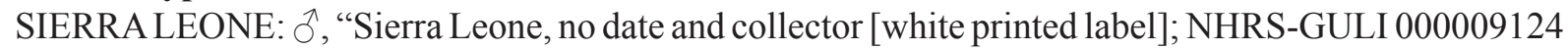
[white printed label]; HOLOTYPE [newly added red printed label]; $\widehat{0}$, Centromeriana lindbergae sp. nov., det. Z.S. Song, I. Malenovský \& A.P. Liang, 2016 [newly added red printed label]" (NHRS, dry-mounted: pinned through mesonotum, right wing apex missing, abdomen detached and stored in glycerine in a glass microvial).

\section{Paratype}

SIERRA LEONE: $1 \hat{\jmath}$, "Sierra Leone [white printed label]; jocosa Gerst, det. Melichar [white handwritten and printed label]; Hung. Nat. Hist. Mus., Budapest, coll. Hemiptera [yellow printed label]; PARATYPUS $\widehat{\jmath}$, Centromeriana lindbergae sp. nov., det. Z.S. Song, I. Malenovský \& A.P. Liang, 2016 [newly added red printed label]" (HNHM, dry-mounted: pinned through mesonotum, abdomen detached and stored in glycerine in a plastic microvial).

\section{Description}

LENGTH. Body length (from apex of head to tip of forewings): $14.3 \mathrm{~mm}$; head length (including two portions: the former is from apex of cephalic process to constricted and curved part, and the latter is from curved part to base of eyes): $\widehat{\partial}(0.7-0.8)+(1.1-1.2)$; head width (including eyes): $\widehat{o} 1.6 \mathrm{~mm}$; forewing length: $\widehat{O}$ 11.4-11.9 mm.

Coloration and external morphology (Figs 1B, 3B, 6A-C). Largely identical to C. jocosa.

Male Genitalia. Pygofer in lateral view (Fig. 6E) similar to C. jocosa, ventral margin much longer than dorsal one with ratio of ventral to dorsal length about 4.2:1; dorso-posterior margin obtusely angular. Gonostyles (Fig. 6E-G) identical to C. jocosa, sicle-shaped, narrow basally, slightly expanding towards apex, broadest subapically; dorsal claw-like process large, elongate, and acute apically. Aedeagus with endosomal processes (Fig. 6H-J) relatively short, membranous, slightly inflated, acute apically, slightly curved with apices directed obliquely dorso-posteriad, apex with minute spines; phallobase sclerotized and pigmented at base, membranous and inflated apically, with one pair of thumb-like dorsolateral lobes, directed anteriad, apex with numerous minute spines (Fig. $6 \mathrm{H}$ ), a pair of long and relatively slender, curved ventral lobes, divergent medially, convergent and tapering apically with some minute superficial spines (Fig. 6I-J). Segment X large and broad in dorsal view, ratio of length to width near middle about 1.3:1 (Fig. 6D); in lateral view, with broad and blunt apical lobes, weakly projecting ventrad (Fig. 6E).

Female unknown.

\section{Distribution}

Sierra Leone.

\section{Remark}

The paratype specimen from HNHM was misidentified and erroneously reported under C. jocosa by Melichar (1912). 


\section{Centromeriana rhinoceros sp. nov. urn:1sid:zoobank.org:act:304EABAF-397A-401C-931F-A8F2D782B702}

Figs $2 \mathrm{~A}, \mathrm{D}, 3 \mathrm{C}, 7 \mathrm{~A}-\mathrm{C}$

\section{Diagnosis}

The species is formally described here in the absence of males but it can be distinguished from all other Centromeriana species by asexual characters, particularly the backward inclination of the cephalic process which also has a relatively smaller size. From $C$. jocosa and $C$. lindbergae sp. nov. it also differs in the clear forewing apex and from $C$. simplex in the body coloration, having a dark pattern, particularly on the abdomen.

\section{Etymology}

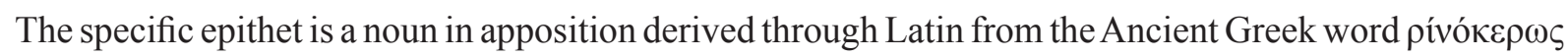

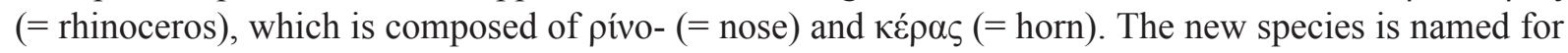
its horn-shaped cephalic process.

\section{Type material examined}

\section{Holotype}

TOGO: +, "Toǵo, Bismarckburǵ, L. Conradt [dark blue printed label]; HOLOTYPE [newly added red printed label]; , Centromeriana rhinoceros sp. nov., det. Z.S. Song, I. Malenovský \& A.P. Liang, 2016 [newly added red printed label]" (MFNB, dry-mounted: pinned through mesonotum).

\section{Paratype}

TOGO: 1 , “Toǵo, Bismarckburǵ, L. Conradt [dark blue printed label]; PARATYPE [newly added yellow printed label]; + , Centromeriana rhinoceros sp. nov., det. Z.S. Song, I. Malenovský \& A.P. Liang, 2016 [newly added red printed label]" (MFNB, dry-mounted: pinned through mesonotum).

\section{Description}

LENGTH. Body length (from apex of head to tip of forewings): $\$ 14.4 \mathrm{~mm}$; head length (including two portions: the former is from apex of cephalic process to constricted and curved part, and the latter is
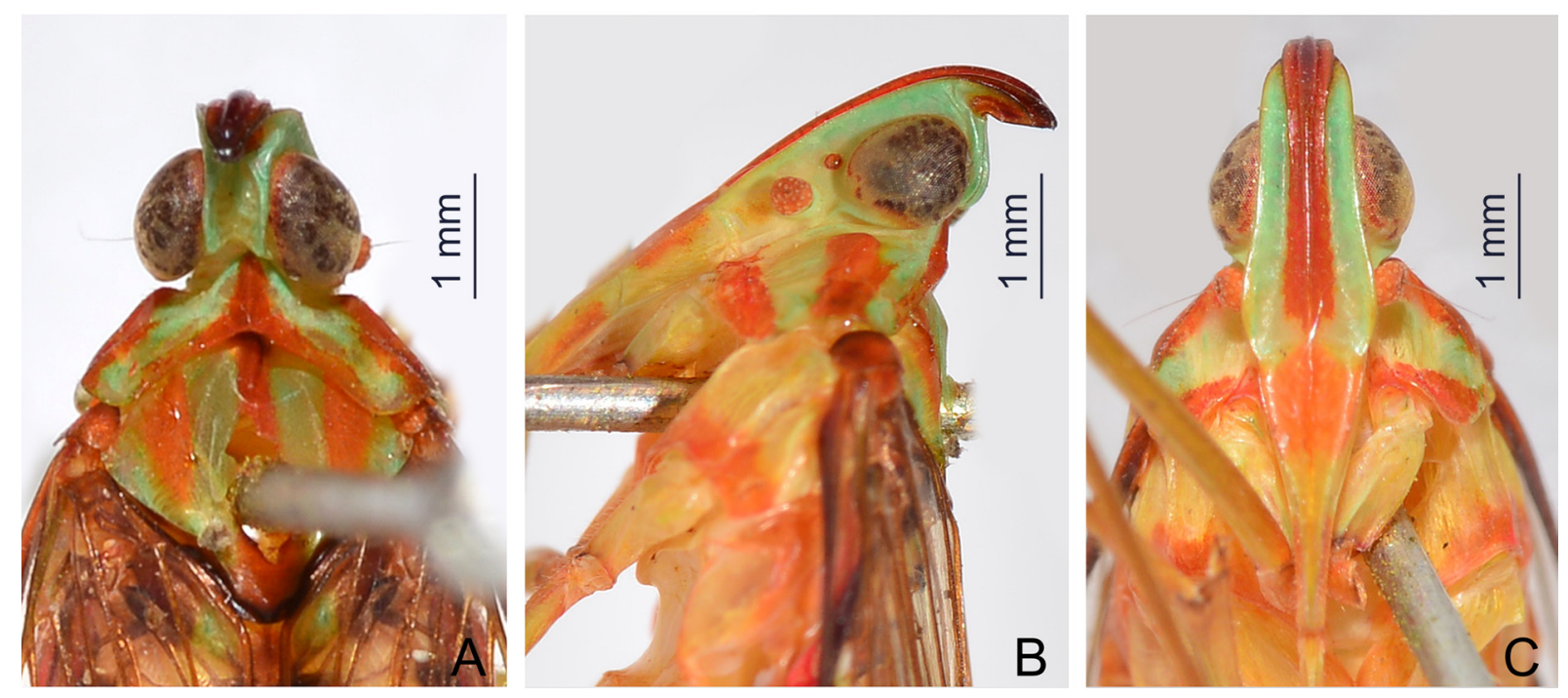

Fig. 7. Centromeriana rhinoceros sp. nov., holotype, .. A. Head, pronotum and mesonotum, dorsal view. B. Head and pronotum, lateral view. C. Head and pronotum, ventral view. 
from curved part to base of eyes): $+0.7+1.0$; head width (including eyes): $q 1.4 \mathrm{~mm}$; forewing length: ㅇ $11.9 \mathrm{~mm}$.

Coloration (Figs 2A, D, 7A-C) AND STRUCTURE. Largely identical to C. jocosa except for the forewing membrane which has clear apex (Fig. 3C). Cephalic process in lateral view relatively short, strongly upturned and curved upward and slightly backward in more than $90^{\circ}$ (Fig. 7B).

Male unknown.

\section{Distribution}

Togo.

Centromeriana simplex Melichar, 1912

Figs 2B, E, 3D, 8A-J

Centromeriana simplex Melichar, 1912: 46. - Metcalf 1946: 40 (catalogue).

\section{Type material examined}

\section{Lectotype (here designated)}

EQUATORIAL GUINEA: đ̃, "Is. Fernando Poo [= Bioko island], Basile, 400-600 m.s.m., VIIIIX.1901, L. Fea; Centromeriana simplex M. [Melichar's handwriting], det. Melichar.; Typus [dark red label]; Syn- typus [bright red label]; Collectio Dr. L. Melichar, Moravské museum Brno; Invent. č. 4940/ Ent., Mor. muzeum, Brno; LECTOTYPUS ${ }^{1}$, Centromeriana simplex Melichar, 1912, desig. Z.S. Song, I. Malenovský \& A.P. Liang, 2016 [newly added red label]" (MMBC; dry-mounted, pinned through mesonotum, abdomen detached and stored in glycerine in a glass microvial pinned under the specimen).

\section{Redescription}

LENGTH. Body length (from apex of head to tip of forewings): $\delta 13.3 \mathrm{~mm}$; head length (including two portions: the former is from apex of cephalic process to constricted and curved part, and the latter is from curved part to base of eyes): $0.7+1.0$; head width (including eyes): $\hat{\jmath} 1.4 \mathrm{~mm}$; forewing length: ○े $10.4 \mathrm{~mm}$.

Coloration (Fig. 2B, E). Largely similar to C. jocosa, but much paler than the latter, without dark brown or black on abdomen in dorsal habitus. Head including cephalic process pale green, a longitudinal stripe in front of eyes on genae and median carina on frons reddish ochraceous (Fig. 8A, C). Pronotum and mesonotum greenish ochraceous, median carina along with posterior margin, areas behind eyes including lower lateral carinae and apical margins of paranotal lobes on pronotum, and median carina and lateral areas on mesonotum reddish ochraceous. Forewings and hindwings with venation and stigmal area pale greenish ochraceous. Abdomen dorsally and ventrally greenish ochraceous. Apical lobes of male segment $\mathrm{X}$ black (Fig. 8E).

Male genitalia. Pygofer in lateral view (Fig. 8E) slightly shorter than in C. jocosa and C. lindbergae sp. nov., ventral margin longer than dorsal one with ratio of ventral to dorsal width about 3.0:1; dorsoposterior margin right-angled. Gonostyles (Fig. 8E-G) broad, strongly expanding towards apex, broadest and convex subapically; dorsal claw-like process narrow and elongate, apex acute. Aedeagus (Fig. 8HJ) lacking distinct endosomal processes; phallobase sclerotized and pigmented at base, membranous and inflated apically, with one pair of large, robust, triangular dorsolateral lobes, directed laterad, without superficial spines (Fig. $8 \mathrm{H}$ ); and one pair of short and thumb-like ventral lobes, directed straightly posteriad (Fig. 8I). Segment $\mathrm{X}$, in dorsal view, elongate with ratio of length to width near middle about 
1.7:1 (Fig. 8D); in lateral view, ventral margins straight, apical lobes blunt, rounded, weakly produced ventrad (Fig. 8E).

Female unknown.
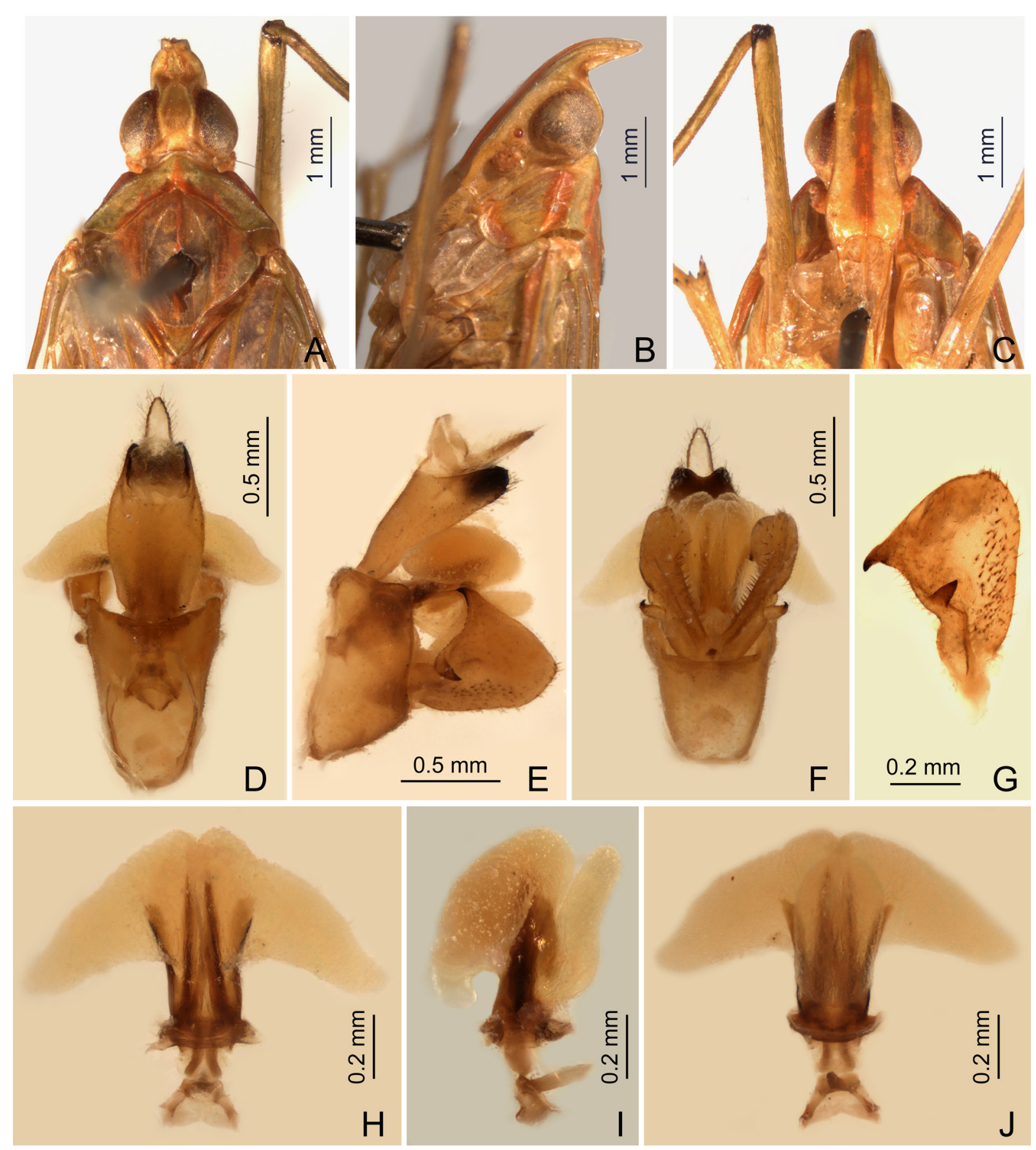

Fig. 8. Centromeriana simplex Melichar, 1912, lectotype, §. A. Head, pronotum and mesonotum, dorsal view. B. Head and pronotum, lateral view. C. Head and pronotum, ventral view. D. Male segment X and pygofer, dorsal view. E. Male pygofer, gonostyles, and segment X, lateral view. F. Male pygofer and gonostyles, ventral view. G. Left gonostyle, outer maximum view. H. Aedeagus, dorsal view. I. Aedeagus, lateral view. J. Aedeagus, ventral view. 


\section{Distribution}

Equatorial Guinea.

\section{Remarks}

This species was described by Melichar (1912) based on two male specimens from Fernando Poo [= Bioko], Equatorial Guinea, originally coming from the collection of the museum in Genoa, Italy. One of these two syntypes has been preserved in Melichar's personal collection in MMBC. According to Article 74 of ICZN (1999) we designate this specimen as a lectotype for C. simplex to stabilize the nomenclature. We have redescribed and illustrated the species based on the lectotype.

\section{Discussion}

In his key to the tribes of Dictyopharinae, Emeljanov (2011) defined Orthopagini by the following combination of characters: wings fully developed, membranous, with forewings projecting far beyond apex of abdomen (except submacropterous genera Macronaso Synave, 1960, Ellipoma Emeljanov, 2008 and Nesolyncides Fennah, 1958; another such genus is Fernandea Melichar, 1912, placed by Emeljanov (2011) in Orthopagini as well, but not listed in the key); veins cariniform; clavus closed; forewing veins $\mathrm{ScR}$ and $\mathrm{M}$ originating from one point of basal cell or closely to each other, without common stem; carina separating apical and basal parts of lateral areas of frons ("acrometope") absent; eyes separated from pronotum by callus postocularis; aedeagus with apical lobes of phallobase spineless or with very short small spines; fore femur usually with ledge or tooth at posterior margin subapically; and apices of $1^{\text {st }}$ and $2^{\text {nd }}$ segments of fore and middle tarsi with no more than two acutellae, surface covered with simple setae. This diagnosis was refined by Song et al. (2016c), who also tested the monophyly of the tribe by cladistic methods but included only the Oriental taxa in their phylogenetic analysis. They revealed Orthopagini as monophyletic if Emeljanovina Xing \& Chen, 2013 was excluded. However, this conclusion still has to be tested based on the world fauna including the Afrotropical taxa.

Besides Centromeriana, five other genera of Orthopagini as defined by Emeljanov (2011) are distributed in the Afrotropical region: Fernandea, Litocras Emeljanov, 2008, Macronaso, Nesolyncides, and Phaenodictyon Fennah, 1958. Centromeriana can be relatively easily distinguished from the macropterous Litocras and Phaenodictyon by the general color marked with pale green and purplishred, the cephalic process being conical and strongly curved upward, and the robust and strongly convex median carina of frons. The monotypic Litocras, known only from South Africa, is greenish with dark brown markings on thorax and legs and lacks the cephalic process and median carina on frons (Emeljanov 2008). Phaenodictyon with two species in western Africa is uniformly greenish/stramineous with conical but straight or only weakly ascending cephalic process, straight median carina of frons, and slightly more robust legs compared to Centromeriana (Fennah 1958a). The other three genera, Fernandea, Macronaso and Nesolyncides, have short coriaceous wings (Fennah 1958b; Emeljanov 2008; Song et al. 2016a) and Centromeriana can be readily differentiated from them by the elongate hyaline forewings extending far beyond the tip of the abdomen.

Melichar (1912) stated that Centromeriana is very similar to the Oriental genus Centromeria Stål, 1870, and can be distinguished from the latter by the fore femora without spine on ventral subapical area. Actually, this small and acute spine can also be absent in some Centromeria species, e.g., C. inspinata Haupt, 1917 (Song et al. 2016c). In habitus, Centromeriana does look very much like the speilinea clade, one of two unambiguous lineages in Centromeria (Song et al. 2016c). Particularly, both taxa share many details of the head structure, such as the cephalic process strongly curved upward and gradually narrowed toward apex; basal width of vertex narrower than transverse diameter of eyes, lateral carinae of vertex abruptly constricted and strongly upturned before eyes, and then gradually convergent anteriorly and acuminate at apex; intermediate carinae of frons distinctly expanded outward at apex so their apical 
portion is distinctly visible in posterodorsal view; median carina of frons robust and strongly convex in lateral view; genae with a longitudinal carina above eyes for apex of cephalic process strongly curved upward, appearing bifurcated from lateral carinae of vertex in lateral view; and very long rostrum.

However, some other characters easily distinguish Centromeriana from Centromeria, such as the female abdominal sternite VII which possesses a pair of large horn-shaped spines directed ventrad near anterior margin and a pair of short and blunt triangular lobes on posterior margin, and the gonocoxae VIII which have a pair of small triangular sclerotized plates on the posterolateral margin of the endogonocoxal lobes. These characters are only found in Centromeriana species and may represent autapomorphies that support monophyly of this genus (females of $C$. lindbergae sp. nov. and C. simplex are, however, unknown at the moment). Centromeriana can also be separated from Centromeria by the following characters: frons with intermediate carinae nearly approaching to frontoclypeal suture (extending only to the middle of eyes in Centromeria); forewings with less transverse veins (distinctly more transverse veins in Centromeria); stigmal area small and quadrangular, with two or three cells (elongate, with 3-5 cells in Centromeria); fore femur without spine (with a minute spine near apex in most Centromeria species); hind tibia with eight apical teeth (with six apical teeth in Centromeria); and the apical spines of the tarsomeres with long setae (with platellae in Centromeria). In addition, the distribution of both genera is different. Centromeriana is endemic to western tropical Africa while Centromeria is distributed in the Indo-Chinese and Indo-Malayan subregions of the Oriental region and Wallacea (Song et al. 2016c).

The common features shared by Centromeriana and Centromeria could be considered as synapomorphic characters which would mean that both genera are closely related sister groups. The big biogeographic disjunction, however, can also imply that the similarities in the head structure might have resulted from a convergent evolution. To resolve this problem, it is necessary to conduct a phylogenetic analysis of the world Orthopagini taxa in future.

\section{Acknowledgements}

We are grateful to Jürgen Deckert, Peter Schönefeld (both MFNB), Gunvi Lindberg (NHRS), Peter Michalik (ZIMG), and Mária Tóth (HNHM) for access to collections under their care and loans of specimens. We also thank Lenka Sentenská (Department of Botany and Zoology, Masaryk University, Brno) for the help with the transport of the type specimen of $C$. jocosa from Greifswald to Brno and back and two anonymous reviewers for useful comments on the manuscript. The work on which this paper is based was supported by the grants from the National Natural Science Foundation of China (no. 31572297, to Z.S.S.; nos. 31561163003, 31572298, and 31372249, to A.P.L.) and the Key Laboratory of the Zoological Systematics and Evolution of the Chinese Academy of Sciences (No. Y229YX5105). Institutional support from the Department of Botany and Zoology, Masaryk University, Brno and MMBC to I.M. is greatly acknowledged as well.

\section{References}

Bartlett C.R., O’Brien L.B. \& Wilson S.W. 2014. A review of the planthoppers (Hemiptera, Fulgoroidea) of the United States. Memoirs of the American Entomological Society 50: 1-287.

Bourgoin T. 1993. Female genitalia in Hemiptera Fulgoromorpha, morphological and phylogenetic data. Annales de la Société entomologique de France (Nouvelle Série) 29: 225-244.

Bourgoin T. 2016. FLOW (Fulgoromorpha Lists On the Web): a world knowledge base dedicated to Fulgoromorpha. Version 8 [online]. Available from http://hemiptera-databases.org/flow/ [accessed on 16 Jan. 2016].

Bourgoin T., Wang R.R., Asche M., Hoch H., Soulier-Perkins A., Stroiński A., Yap S. \& Szwedo J. 2015. From micropterism to hyperpterism: recognition strategy and standardized homology-driven terminology 
SONG Z.S. et al., Revision of the planthopper genus Centromeriana

of the forewing venation patterns in planthoppers (Hemiptera: Fulgoromorpha). Zoomorphology 134: 63-77. http://dx.doi.org/10.1007/s00435-014-0243-6

Emeljanov A.F. 1983. Dictyopharidae from the Cretaceous deposits on the Taymyr Peninsula (Insecta, Homoptera). Paleontologicheskii Zhurnal 3: 79-85.

Emeljanov A.F. 2008. New genera and new species of the family Dictyopharidae (Homoptera), with notes on the systematics of the subfamily Dictyopharinae. Entomological Review 88 (3): 296-328. http://dx.doi.org/10.1134/S0013873808030056

Emeljanov A.F. 2011. Improved tribal delimitation of the subfamily Dictyopharinae and description of new genera and new species (Homoptera, Fulgoroidea, Dictyopharidae). Entomological Review 91 (9): 1122-1145.http://dx.doi.org/10.1134/s0013873811090053

Emeljanov A.F. \& Shcherbakov D.E. 2011. A new genus and species of Dictyopharidae (Homoptera) from Rovno and Baltic amber based on nymphs. Zookeys 130: 175-184. http://dx.doi.org/10.3897/ zookeys.130.1775

Fennah R.G. 1958a. Fulgoroidea from the Belgian Congo (Hemiptera: Homoptera). Annales du Musée du Congo belge (Sciences zoologique), Ser. 859 (1957): 1-206.

Fennah R.G. 1958b. Fulgoroidea from West Africa. Bulletin de l'Institut français Afrique noire, Ser. A, 20: 460-538.

Gerstaecker C.E.A. 1895. Ueber einige bemerkenswerthe Fulgorinen der Greifswalder zoologischen Sammlung. Mittheilungen des Naturwissenschaftlichen Vereines für Neu-Vorpommern und Rügen 27: $1-50$.

Heinrichs E.A. \& Barrion A.T. 2004. Rice-feeding insects and selected natural enemies in West Africa: biology, ecology, identification. International Rice Research Institute, Los Baños (Philippines) and WARDA-The Africa Rice Center, Abidjan (Côte d'Ivoire).

ICZN (International Commission on Zoological Nomenclature) 1999. International Code of Zoological Nomenclature. Fourth Edition. The International Trust for Zoological Nomenclature c/o the Natural History Museum, London. http://dx.doi.org/10.5962/bhl.title.50608

Lallemand V. 1958. Homoptères. La Réserve naturelle intégrale du Mont Nimba, IV. Mémoires de l'Institut fondamental d'Afrique noire 53: 219-228.

Liang A.P. \& Song Z.S. 2006. Revision of the Oriental and eastern Palaearctic planthopper genus Saigona Matsumura, 1910 (Hemiptera: Fulgoroidea: Dictyopharidae), with descriptions of five new species. Zootaxa 1333: 25-54.

Linder H.P., de Klerk H.M., Born J., Burgess N.D., Fjeldsa J. \& Rahbek C. 2012. The partitioning of Africa: statistically defined biogeographical regions in sub-Saharan Africa. Journal of Biogeography 39: 1189-1205. http://dx.doi.org/10.1111/j.1365-2699.2012.02728.x

Melichar L. 1912. Monographie der Dictyophorinen (Homoptera). Abhandlungen der KöniglichKaiserlichen Zoologisch-Botanischen Gesellschaft in Wien 7 (1): 1-221.

Metcalf Z.P. 1946. General catalogue of the Hemiptera, Fasci. IV. Fulgoroidea, Part 8 Dictyopharidae. Smith College, Northampton. http://dx.doi.org/10.1093/aesa/40.3.544

Oke O.A., Odiyi C.A. \& Ofuya T.I. 2015. Insects associated with underutilized crop: grain, leafy and ornamental amaranth in Ibadan, Nigeria. Journal of Agriculture and Ecology Research International 2 (2): 145-155. http://dx.doi.org/10.9734/JAERI/2015/14227

Schmidt E. 1915. Die Dictyopharinen des Stettiner Museums (Hemiptera-Homoptera). Stettiner Entomologische Zeitung 76: 345-358. 
Song Z.S. \& Liang A.P. 2006a. First record of the genus Dictyopharina Melichar (Hemiptera: Fulgoroidea: Dictyopharidae) from China, with descriptions of two new species. Zootaxa 1166: 21-33.

Song Z.S. \& Liang A.P. 2006b. Two new species of the genus Dictyopharina Melichar (Hemiptera: Fulgoroidea: Dictyopharidae) from Southeast Asia. Acta Zootaxonomica Sinica 31: 595-600. http:// dx.doi.org/10.3969/j.issn.1000-0739.2006.03.031

Song Z.S. \& Liang A.P. 2007. A new species of the Oriental planthopper genus Tenguna Matsumura, 1910 (Hemiptera: Fulgoroidea: Dictyopharidae) from Xizang, China. Zootaxa 1439: 57-64.

Song Z.S. \& Liang A.P. 2011. Two new genera and two new species of Oriental dictyopharid planthoppers (Hemiptera: Fulgoromorpha: Dictyopharidae) from Sri Lanka and southern India. Zootaxa 2740: 24-34.

Song Z.S. \& Liang A.P. 2012a. Taxonomic revision of the Oriental genus Metaurus Stål (Hemiptera: Fulgoromorpha: Dictyopharidae), with description of a new species. Journal of Natural History 46: 2563-2575. http://dx.doi.org/10.1080/00222933.2012.708456

Song Z.S. \& Liang A.P. 2012b. Dictyotenguna choui, a new genus and species of Dictyopharinae (Hemiptera: Fulgoromorpha: Dictyopharidae) from China. Entomotaxonomia 34 (2): 207-214.

Song Z.S., Deckert J. \& Liang A.P. 2012. Revision of the Oriental genus Leprota Melichar (Hemiptera, Fulgoromorpha, Dictyopharidae), with description of a new species from northern Borneo, Malaysia. Deutsche Entomologische Zeitschrift 59: 219-226.

Song Z.S., Webb M.D. \& Liang A.P. 2014. Systematic revision of the Oriental planthopper genus Miasa Distant (Hemiptera: Fulgoromorpha: Dictyopharidae), with description of a new genus from southern India. Arthropod Systematics \& Phylogeny 72: 137-164.

Song Z.S., Malenovský I. \& Liang A.P. 2016a. Revision of the Afrotropical genus Fernandea Melichar, 1912 (Hemiptera: Fulgoromorpha: Dictyopharidae), with description of a new species from Equatorial Guinea. Zootaxa 4139: 106-116. http://dx.doi.org/10.11646/zootaxa.4139.1.6

Song Z.S., Szwedo J., Wang R.R. \& Liang A.P. 2016b. Systematic revision of Aluntiini Emeljanov, 1979 (Hemiptera: Fulgoromorpha: Dictyopharidae: Dictyopharinae): reclassification, phylogenetic analysis, and biogeography. Zoological Journal of the Linnean Society 176: 349-398. http://dx.doi.org/10.1111/ $\underline{\text { zoj. } 12319}$

Song Z.S., Webb M.D. \& Liang A.P. 2016c. Phylogenetic analysis of the Oriental genera of Orthopagini, Emeljanov, 1983 (Hemiptera: Fulgoromorpha: Dictyopharidae: Dictyopharinae), with a systematic revision of the genus Centromeria Stal, 1870. Zoological Journal of the Linnean Society 178: 33-87. http://dx.doi.org/10.1111/zoj.12401

Stroiński A. \& Szwedo J. 2015. Why so scarce? Dictyopharidae from Madagascar (Hemiptera: Fulgoromorpha). Zootaxa 4033: 363-379. http://dx.doi.org/10.11646/zootaxa.4033.3.3

Urban J.M. \& Cryan J.R. 2009. Entomologically famous, evolutionarily unexplored: The first phylogeny of the lanternfly family Fulgoridae (Insecta: Hemiptera: Fulgoroidea). Molecular Phylogenetics and Evolution 50: 471-484. http://dx.doi.org/10.1016/j.ympev.2008.12.004

White F. 1979. The Guineo-Congolian Region and its relationship to other phytochoria. Bulletin $d u$ Jardin botanique national de Belgique 49: 11-55.

White F. 1983. The vegetation of Africa. A descriptive memoir to accompany the UNESCO/AETFAT/ UNSO vegetation map of Africa. UNESCO, Paris.

Wilson S.W., Mitter C., Denno R.F. \& Wilson M.R. 1994. Evolutionary patterns of host plant use by delphacid planthoppers and their relatives. pp. 7-113. In: Denno R.F. \& Perfect T.J. (eds) Planthoppers: 
their ecology and management. Chapman and Hall, New York. http://dx.doi.org/10.1007/978-1-4615$\underline{2395-62}$

Manuscript received: 1 February 2016

Manuscript accepted: 1 August 2016

Published on: 15 February 2017

Topic editor: Gavin Broad

Desk editor: Laurence Bénichou and Kristiaan Hoedemakers

Printed versions of all papers are also deposited in the libraries of the institutes that are members of the EJT consortium: Muséum national d'Histoire naturelle, Paris, France; Botanic Garden Meise, Belgium; Royal Museum for Central Africa, Tervuren, Belgium; Natural History Museum, London, United Kingdom; Royal Belgian Institute of Natural Sciences, Brussels, Belgium; Natural History Museum of Denmark, Copenhagen, Denmark; Naturalis Biodiversity Center, Leiden, the Netherlands. 